\title{
COMPOUND-SPECIFIC RADIOCARBON DATING OF ESSENTIAL AND NON- ESSENTIAL AMINO ACIDS: TOWARDS DETERMINATION OF DIETARY RESERVOIR EFFECTS IN HUMANS
}

\author{
Shweta Nalawade-Chavan ${ }^{1} \cdot$ James McCullagh $^{2} \cdot$ Robert Hedges $^{1} \bullet$ Clive Bonsall $^{3} \cdot$ \\ Adina Boroneant $t^{4} \bullet$ Christopher Bronk Ramsey ${ }^{1}$ Thomas Higham ${ }^{1}$
}

\begin{abstract}
When humans consume foods from different radiocarbon reservoirs offset in age to the atmosphere, inaccuracies in the ${ }^{14} \mathrm{C}$ date of bone collagen can occur. Mesolithic human skeletons from the Iron Gates section of the Lower Danube Valley have yielded reservoir offsets of up to $\sim 500 \mathrm{yr}$. This has been demonstrated through direct dating of bulk collagen from human bones and the remains of ungulate bone projectile points that were found embedded in them (Cook et al. 2001). We present improvements to a novel HPLC method for the detection and separation of underivatized amino acids using a wateronly mobile phase free of organic or inorganic modifiers, ensuring very low carbon backgrounds. Our hypothesis is that direct ${ }^{14} \mathrm{C}$ dating of single essential and non-essential amino acids might allow an improvement in the dating accuracy for reservoiraffected human bones. The method facilitates separation of less polar amino acids (mostly "essential"), currently not possible in the recently published protocol. We discuss methodological developments, demonstrate carbon backgrounds, and present analytical approaches to minimize their effects. We validate the precision and accuracy of the method by accelerator mass spectrometry (AMS) dating relatively modern and ${ }^{14} \mathrm{C}$-dead, known-age bone standards. Finally, we apply the method to the dating of single amino acids from bone samples with a proven $\sim 500$-yr carbon reservoir effect from Mesolithic burials at the Iron Gates sites. We investigate whether differences can be found in AMS dates for essential and non-essential amino acids since, although contemporaneous, these are expected to derive from dietary sources with differing ${ }^{14} \mathrm{C}$ reservoirs.
\end{abstract}

\section{INTRODUCTION}

Prehistorians using radiocarbon dating commonly target bone to build archaeological chronologies. It has become apparent over recent years, however, that the source or sources from which the organism obtained its organic carbon has a great influence on the ${ }^{14} \mathrm{C}$ age. This is especially acute for omnivores. Dietary carbon can potentially come from a variety of carbon reservoirs that contribute to the diet. These reservoirs may comprise a different ${ }^{14} \mathrm{C}$ concentration to the contemporary atmosphere, giving rise to "apparent" ages. Many serious problems with ${ }^{14} \mathrm{C}$ dating can be linked to reservoir effects where carbon from different terrestrial, marine, or freshwater reservoirs, having a differing ${ }^{14} \mathrm{C}$ age, is taken up by organisms and incorporated in the bone collagen (Beavan and Sparks 1998; Beavan-Athfield et al. 2001). This carbon ultimately can derive from a variety of sources such as volcanic $\mathrm{CO}_{2}$ vent emission (Bruns et al. 1980), dissolved geological carbonates, marine deepwater dissolved carbonate, freshwater organic and inorganic carbon, as well as soil carbon (Cook et al. 2001, 2002; Higham et al. 2010). The marine reservoir effect is the most well known. On average, there is a depletion of $\sim 400 \mathrm{yr}$ in oceanic ${ }^{14} \mathrm{C}$ compared with terrestrial and atmospheric values (Reimer et al. 2004, 2009).

Where human bone collagen is used for ${ }^{14} \mathrm{C}$ dating, any dietary reservoir effect must be evaluated, usually with stable $\mathrm{C}$ and $\mathrm{N}$ isotopes, which inform us about dietary protein sources within the food chain. Analysis at the single amino acid level has the potential to provide more information on dietbased reservoir effects since different amino acids take different metabolic routes from diet to collagen. It is well known that essential amino acids (EEAs) must come directly from dietary protein because animals lack the enzymes required for their biosynthesis (Devlin 1998). Non-essential

\footnotetext{
${ }^{1}$ Research Laboratory for Archaeology and the History of Arts, University of Oxford, Oxford OX1 3QY, United Kingdom. ${ }^{2}$ Chemistry Research Laboratory, University of Oxford, Oxford OX1 3TA, United Kingdom.

${ }^{3}$ School of History, Classics and Archaeology, University of Edinburgh, Edinburgh EH8 9AG, United Kingdom.

4'Vasile Pârvan' Institute of Archaeology, Romanian Academy, 11 Henri Coandă St., 010667 Bucharest, Romania.
} 


\section{S Nalawade-Chavan et al.}

amino acids (NEAAs), however, may be biosynthesized using carbon-containing substrates from a variety of dietary macronutrients, and this has been demonstrated by several feeding studies (Reeds 2000; Ambrose and Norr 1993; Jim et al. 2006). In a case where marine or freshwater proteins as well as terrestrial carbohydrates are being consumed, NEAAs are thought more likely to contain proportionally higher ${ }^{14} \mathrm{C}$ content than the more depleted reservoir ${ }^{14} \mathrm{C}$ found in EAAs. Under such circumstances, we would expect to find a difference in ${ }^{14} \mathrm{C}$ dates of EAAs and NEAAs from the same individual. Finding such differences would therefore provide a biomarker for the presence of reservoir carbon and hence allow us to identify the presence of multiple carbon reservoirs in human bone, and to do so without recourse to the dating of associated materials (if possible).

This hypothesis initiated the Oxford Radiocarbon Accelerator Unit's (ORAU) novel approach to ${ }^{14} \mathrm{C}$ dating single amino acids separated from bone collagen (McCullagh et al. 2010). The previous reported method focused on removing contamination by separating hydroxyproline for dating using a preparative HPLC (high-pressure liquid chromatography) method. This involved a complex phosphoric acid gradient followed by a second injection to remove acid from the collected fractions (Marom et al. 2012). Prolonged chromatographic run times and the inability to separate strongly retained EAAs have hampered wider application of the method to investigate issues such as reservoir effects.

Here, we report significant improvements to the method that enable quicker separation of a range of amino acids from bone collagen, making the method suitable both for routine ${ }^{14} \mathrm{C}$ dating of hydroxyproline for analyzing contaminated bone samples and the investigation of diet-based reservoir carbon by accelerator mass spectrometry (AMS) dating non-essential single amino acids. ${ }^{14} \mathrm{C}$ dates of many Mesolithic human burials from sites in the Iron Gates region of the Danube River are $\sim 500 \mathrm{yr}$ older than the terrestrial mammal bones found in direct association with them. The isotopic values of these humans suggest that $\sim 80 \%$ of diet proteins may have been derived from fish consumption (Cook et al. 2001). These human bones are well suited to investigate whether differences can be found in ${ }^{14} \mathrm{C}$ dates for EAAs and NEAAs and whether single NEAA dates correspond to the real age of the sample.

\section{MATERIAL AND METHODS}

\section{Materials, Reagents, and Standards}

Amino acid standards were purchased from Sigma-Aldrich Ltd (Sigma-Aldrich, Wincanton, UK). Purified Milli-Q ${ }^{\mathrm{TM}}$ (typically $18.2 \mathrm{M}$ resistivity and $<4 \mathrm{ppb}$ carbon) water was used throughout the experiments. All other chemicals were HPLC grade and purchased from Fisher (Fisher Scientific UK, Leics, UK) and Sigma-Aldrich. Glassware and Chromosorb ${ }^{\mathrm{TM}}$ was baked at $500{ }^{\circ} \mathrm{C}$ for $3 \mathrm{hr}$ prior to use.

\section{Archaeological and Historical Bone Standards}

Two known-age bones, pig bone from the Mary Rose shipwreck (which sank in AD 1545, age $321 \pm$ $6.5 \mathrm{yr} \mathrm{BP}$ ) and a very old $>45 \mathrm{kyr}$ Alaskan permafrost bison bone, were used to check modern and background carbon levels and to validate single amino acid dates.

\section{Sample Preparation}

Collagen was extracted using standard procedures at ORAU (Longin 1971; O'Connell and Hedges 1998; O'Connell et al. 2001). Bone samples were sandblasted to clean surface detritus before any chemical pretreatment. Modern bone samples were defatted by sonicating in methanol and chloro- 


\section{Compound-Specific ${ }^{14}$ C Dating of Amino Acids}

form $(2: 1 \mathrm{v} / \mathrm{v})$ for $3 \mathrm{hr}$, changing the solvent at least 5 times until all fat was removed. This was followed by 3 repetitions of ultrasonication in water for $30 \mathrm{~min}$.

The cleaned, defatted, finely ground bone samples were demineralized by adding $0.5 \mathrm{M} \mathrm{HCl}$. The samples were left in a refrigerator during this time. The acid was changed every 2 days until the samples became soft and the effervescence ceased. The supernatant was decanted, and the remaining pellet was gelatinized by heating in dilute $\mathrm{HCl}$ solution $(1 \mathrm{mM}, \mathrm{pH} \mathrm{3.0})$ at $75^{\circ} \mathrm{C}$ for $24 \mathrm{hr}$. The acidinsoluble residue was removed by centrifugation. The solution was then freeze-dried in preweighed tubes. For bulk AMS dating, the intact collagen was used for graphitization.

Prior to chromatography, it is necessary to break the protein chain in bone collagen down into its constituent amino acids by hydrolysis. For this, $\sim 50-\mathrm{mg}$ aliquots of collagen were treated with an excess of $6 \mathrm{M} \mathrm{HCl}$ in a nitrogen atmosphere at $105^{\circ} \mathrm{C}$ for $24 \mathrm{hr}$, which was then removed using a Genevac EZ-2 vacuum evaporator (Genevac Ltd, Ipswich, UK). The residue was washed with Milli$\mathrm{Q}$ water and freeze-dried to remove residual acid (if any) and evaporated to dryness again. The dried residue was then reconstituted in $5 \mathrm{~mL}$ of dilute $\mathrm{HCl}$ solution $(1 \mathrm{mM}, \mathrm{pH} 3.0)$ to a concentration of $\sim 10 \mathrm{mg} \mathrm{mL}^{-1}$. This hydrolysate solution was filtered through $0.2-\mu$ PTFE syringe filters and $1 \mathrm{~mL}$ of solution was injected onto the chromatographic column.

\section{Preparative Scale High-Pressure Liquid Chromatography (HPLC)}

A Varian ProStar HPLC equipped with a titanium head, isocratic pumps, an autosampler, a UV detector set at $205 \mathrm{~nm}$, and a fraction collector controlled by Star workstation PC software was used. Mobile phases were continuously sparged with $\mathrm{N}_{2}$ gas produced using Nitrogen Generator (Model 76-940220, Whatman Inc., Haverill, MA, USA). Our novel water-only mobile phase separation method involves 2 steps:

1. Separation of EAAs on a reversed-phase chromatographic column: A solution containing $\sim 10 \mathrm{mg}$ of hydrolyzed bone collagen was injected on a $\mathrm{dC}_{18}$ Atlantis ${ }^{\mathrm{TM}}$ column $(19 \times 100 \mathrm{~mm}$, particle size $5 \mu \mathrm{m}$, Waters Inc., Milford, MA, USA) using $3 \mathrm{~mL} \mathrm{~min}{ }^{-1}$ Milli-Q water as a mobile phase. This is a silica-based, reversed-phase $\mathrm{C}_{18}$ column and features di-functionally bonded $\mathrm{C}_{18}$ ligands that have been optimized for use with highly aqueous mobile phases, including $100 \%$ water. NEAA were collected all together with valine at around 8 min. EAAs such as methionine (Met), leucine (Leu), isoleucine (Ile), tyrosine (Tyr), and phenylalanine (Phe) were collected as separate peaks (Figure 1) and, being in low abundance in collagen, were pooled together to obtain sufficient quantity required for AMS dating.

2. Separation of NEAAs on a mixed-mode chromatographic column: The NEAA fraction collected on $\mathrm{dC}_{18}$ Atlantis column was evaporated to dryness using the Genevac and reconstituted in $1 \mathrm{~mL}$ of dilute $\mathrm{HCl}$ solution $(1 \mathrm{mM}, \mathrm{pH} 3.0)$, then injected onto a Primesep A column $(22 \times$ $250 \mathrm{~mm}$, particle size $5 \mu \mathrm{m}$; SIELC, IL, USA) using $15 \mathrm{~mL} \mathrm{~min}^{-1}$ Milli-Q water as a mobile phase. This is a mixed-mode separation column combining reversed-phase (RP) interactions provided by the stationary phase (C-12 alkyl groups bonded to the surface of the silica backbone) with ion exchange interactions provided by an additional charge on the surface via ionized carboxylic acid groups. As the embedded group is negatively charged in the whole working $\mathrm{pH}$ range (2-6), it is not necessary to control the $\mathrm{pH}$ of the water. The stationary phase's ability to interact is influenced by the $\mathrm{pH}$ of the mobile phase, as is the charge state of the amino acids in the mobile-phase solution. NEAA such as aspartic acid (Asp), glutamic acid (Glu), hydroxyproline (Hyp), serine (Ser), threonine (Thr), glycine (Gly), proline (Pro), and alanine (Ala) were collected as separate peaks (Figure 2). Column overloading was avoided to ensure that an acceptable resolution is achieved. 


\section{S Nalawade-Chavan et al.}

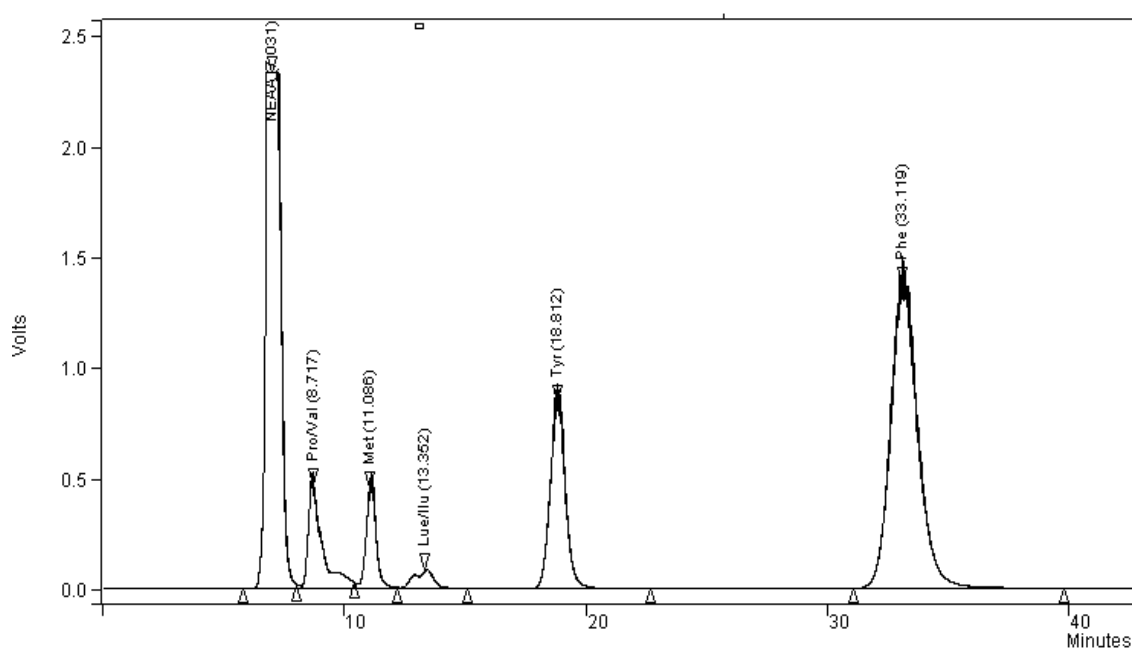

Figure 1 Typical chromatogram for separation of essential amino acids from hydrolyzed bone collagen on $\mathrm{dC}_{18}$ Atlantis column (1st injection)

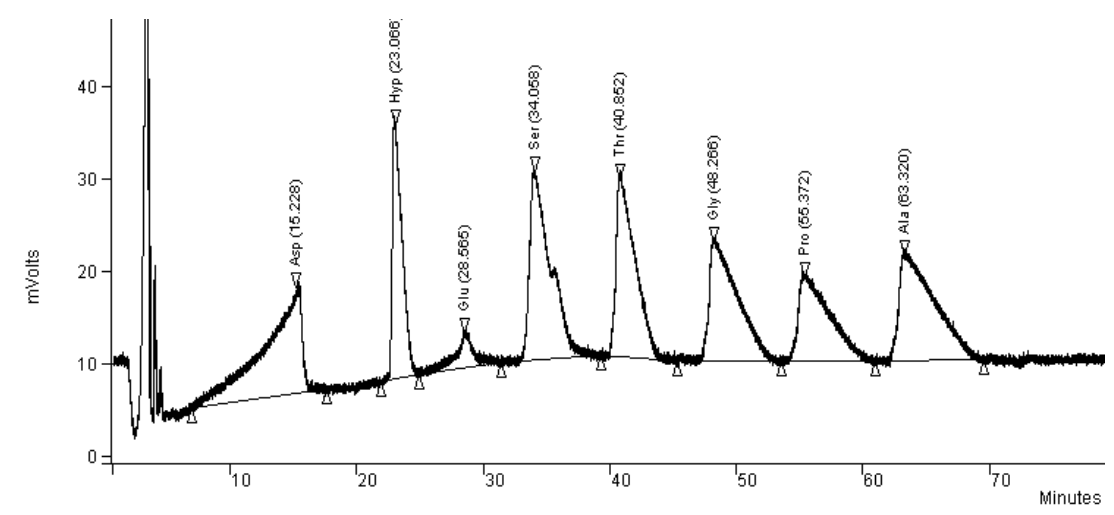

Figure 2 Typical chromatogram for separation of non-essential amino acid on Primesep A column (2nd injection).

Working standard solutions containing individual amino acids and mixtures of each amino acid were used to identify chromatographic peaks and the elution order of amino acids. For each sample, 3 to 5 injections of $10 \mathrm{mg}$ hydrolyzed collagen were made in order to collect each amino acid corresponding to $\sim 1 \mathrm{mg}$ of carbon for each amino acid after combustion. Fractions were evaporated using a Genevac EZ-2 vacuum evaporator.

After each injection, the Primesep A column was washed with $0.3 \%$ o-phosphoric acid for $2 \mathrm{hr}$ to make all the mixed-mode interaction sites available and washed with water at a flow rate of $15 \mathrm{~mL} \mathrm{~min}^{-1}$ for at least $3 \mathrm{hr}$ before the next injection. Both columns were stored in $0.3 \%$ o-phosphoric acid when not in use. The amino acid fractions collected were evaporated to dryness using the Genevac and reconstituted in dilute $\mathrm{HCl}$ solution $(1 \mathrm{mM}, \mathrm{pH} 3.0)$ to facilitate their loading onto Chromosorb in tin capsules prior to combustion. This was undertaken using an elemental analyzer (Carlo Erba NA 2000) linked to a continuous-flow isotope ratio mass spectrometer (CF-IRMS Sercon 20-20). A portion of gas was fed into the mass spectrometer and the remaining $\mathrm{CO}_{2}$ was col- 
Compound-Specific ${ }^{14} \mathrm{C}$ Dating of Amino Acids

lected, converted to graphite, and dated by AMS as per ORAU's routine procedures for combustion, graphitization, and AMS dating (Brock et al. 2010).

\section{Estimation and Optimization of Background Carbon}

It is essential to ensure that the pretreatment procedures used do not add significant amounts of carbon contamination. The extraneous carbon resulting from the extra steps involved in separating single amino acids using chromatographic technique comes from 2 sources: 1) from the stationary phase: ${ }^{14} \mathrm{C}$-dead carbon contamination added due to HPLC column bleed; and 2) from the mobile phase: modern carbon contamination added due to dissolved atmospheric $\mathrm{CO}_{2}$ and total organic carbon (TOC) in the Milli-Q water used.

The amount of column bleed is directly proportional to the amount of acid present in the mobile phase (McCullagh et al. 2010). Water-only elution gives the best possibility of having the lowest column bleed. Also, fractions with $\mathrm{pH}$ adjusted to 2 were found to contain the lowest amount of dissolved atmospheric $\mathrm{CO}_{2}$.

The amount of total extraneous carbon added per $\mathrm{mL}$ of fraction collected was estimated using an elemental analyzer and isotope ratio mass spectrometry (IRMS). To assess the linearity of the extraneous carbon added, different aliquots of HPLC effluent collected from blank injections using the Primesep A column were evaporated to dryness after adjusting the $\mathrm{pH}$ to 2 . The amount of carbon in each aliquot was estimated and plotted against the volume to establish a linear plot with a coefficient of correlation of 0.935 . To assess the repeatability of the background carbon added during HPLC, 500-mL aliquots of mobile-phase effluent were collected and evaporated to dryness after adjusting the $\mathrm{pH}$ to 2 . The relative standard deviation (SD) for $n=5$ was $15.0 \%$ and $25.1 \%$ for the Primesep A and $\mathrm{dC}_{18}$ Atlantis column, respectively, at $\sim 0.030 \mu \mathrm{g} \mathrm{mL}{ }^{-1}$ of carbon. For this, $500 \mathrm{~mL}$ of the mobile phase was collected from a blank injection after passing through the chromatographic system with an HPLC column and was found to be $0.032 \mu \mathrm{g} \mathrm{mL}-1$ with Primesep A column (SD = $0.008 \%$, for $n=5$ ) and $0.025 \mu \mathrm{g} \mathrm{mL}^{-1}$ for $\mathrm{dC}_{18}$ Atlantis column ( $\mathrm{SD}=0.003 \%$, for $n=5$ ). The amount of modern carbon per $\mathrm{mL}$ of mobile phase collected was estimated in a similar way but without using the HPLC column, and was found to be $0.006 \mu \mathrm{g} \mathrm{mL}^{-1}(\mathrm{SD}=0.003 \%$ for $n=5$ ). The difference corresponds to the amount of ${ }^{14} \mathrm{C}$-dead carbon, $0.0026 \mu \mathrm{g} \mathrm{mL}-1$ resulting from Primesep column bleed and $0.019 \mu \mathrm{g} \mathrm{mL}^{-1}$ resulting from $\mathrm{dC}_{18}$ Atlantis column bleed. From these values and the amount of mobile phase collected, the amount of extraneous carbon added to each amino acid was calculated.

\section{Correction Algorithm for Single Amino Acid Radiocarbon Dates}

The amino acid dates in Table 1 are corrected for routine procedures such as pretreatment chemistry, combustion, and graphitization and for the carbon contamination derived from the chromatographic separation step:

- For an uncontaminated sample: ${ }^{14} \mathrm{C}$ age: $T=-8033 \ln \left(\mathrm{F}^{14} \mathrm{C}\right)$

- For a sample contaminated by extraneous dead and modern carbon: Corrected ${ }^{14} \mathrm{C}$ age, $T_{C}=$ $-8033 \ln \left(\mathrm{F}^{14} \mathrm{C} C_{m o d}\right) / b$

where $\mathrm{F}^{14} \mathrm{C}=$ measured activity, $C_{\text {mod }}=$ modern $\mathrm{C}$ contamination $(\mathrm{mg}) /$ total $\mathrm{C}(\mathrm{mg})$, and $b=$ $\frac{C_{\text {Total }}(m g)-\text { Modern C Contamination }(m g)-\text { Dead C Contamination }(\mathrm{mg})}{C_{\text {Total }}(\mathrm{mg})}$. 


\section{S Nalawade-Chavan et al.}

A combined error term was calculated by taking the procedural error for estimation of dead and modern carbon contamination and the $\pm 1 \sigma$ error into account:

$$
\text { Combined error }=\mathrm{F}^{14} \mathrm{C}^{\prime} \sqrt{\left(\frac{E_{\mathrm{F}^{14} \mathrm{C}}}{\left(\mathrm{F}^{14} \mathrm{C}-C_{\text {mod }}\right)}\right)^{2}+\left(\frac{E_{\text {mod }}}{C_{\text {Total }}}\right)^{2}\left(\frac{1}{b}-\frac{1}{\left(\mathrm{~F}^{14} \mathrm{C}-C_{\text {mod }}\right)}\right)^{2}+\left(\frac{E_{\text {dead }}}{b \times C_{\text {Total }}}\right)^{2}}
$$

where $\mathrm{F}^{14} \mathrm{C}^{\prime}$ is the corrected activity $=\left(\mathrm{F}^{14} \mathrm{C}-C_{m o d}\right) / b ; C_{\text {Total }}$ is graphite size $(\mathrm{mg}) ; E_{\text {dead }}$ is the procedural error in estimation of dead carbon contamination (for $n=5$ ); $E_{m o d}$ is the procedural error in estimation of modern carbon contamination (for $n=5$ ); and $E_{\mathrm{F}^{14} \mathrm{C}}= \pm 1 \sigma$ error in determination of ${ }^{14} \mathrm{C}$ activity.

\section{RESULTS}

An Alaskan permafrost bison bone, a ${ }^{14} \mathrm{C}$-dead material, is used at the ORAU as a laboratory background standard (Brock et al. 2010). To ensure acceptable levels of background, hydroxyproline fractions were separated using the method described and the ${ }^{14} \mathrm{C}$ dates obtained were corrected for the carbon contamination added during chromatography by applying the correction algorithm. All the hydroxyproline dates were close to the background levels of ${ }^{14} \mathrm{C}$ measurement and suggested infinite dates.

\section{Single Amino Acid Radiocarbon Dates for Mary Rose Pig Bone Standard}

Pig bones from the Mary Rose ship are used at the ORAU as a modern standard. This sample has previously provided bulk collagen AMS dates of $321 \pm 6.5 \mathrm{yr}$ BP from about 40 measurements. The bulk collagen dates for this material range from 280 to $390 \mathrm{yr}$ BP depending on the collagen yield (Bronk Ramsey et al. 2004a,b). For this material, individual amino acid dates should correspond directly to bulk collagen and historical dates, within standard errors. Table 1 lists ${ }^{14} \mathrm{C}$ dates for single amino acids separated from the Mary Rose pig bone collagen using the updated method described in this paper. Each date was corrected for the amount of ${ }^{14} \mathrm{C}$-dead and modern carbon contamination added during chromatography.

Table 1 Mary Rose pig bone amino acid AMS dates after correcting for the addition of extraneous carbon during chromatographic separation.

\begin{tabular}{|c|c|c|c|c|c|c|}
\hline $\begin{array}{l}\text { Amino acid/ } \\
\text { Lab nr }\end{array}$ & $\begin{array}{l}{ }^{14} \mathrm{C} \text { age } \\
\mathrm{BP}( \pm 1 \sigma)\end{array}$ & $\mathrm{F}^{14} \mathrm{C}( \pm 1 \sigma)$ & $\begin{array}{l}\text { Vol. } \\
(\mathrm{mL})\end{array}$ & $\begin{array}{l}\mathrm{C} \\
(\mathrm{mg})\end{array}$ & $\begin{array}{l}\text { Corrected } \mathrm{F}^{14} \mathrm{C} \\
( \pm 1 \sigma)\end{array}$ & $\begin{array}{l}\text { Corrected }{ }^{14} \mathrm{C} \\
\text { age BP }( \pm 1 \sigma)\end{array}$ \\
\hline $\begin{array}{l}\text { Asp } \\
\text { X-2423-26 }\end{array}$ & $420 \pm 28$ & $0.94905 \pm 0.00331$ & 270 & 0.67 & $0.95900 \pm 0.00335$ & $336 \pm 28$ \\
\hline $\begin{array}{l}\text { Hyp } \\
\text { X-2423-27 }\end{array}$ & $390 \pm 24$ & $0.95267 \pm 0.00285$ & 180 & 1.69 & $0.95529 \pm 0.00286$ & $367 \pm 24$ \\
\hline $\begin{array}{l}\text { Glu } \\
\text { X-2423-28 }\end{array}$ & $400 \pm 26$ & $0.95144 \pm 0.00303$ & 240 & 0.90 & $0.95802 \pm 0.00306$ & $344 \pm 26$ \\
\hline $\begin{array}{l}\text { Gly } \\
\text { X-2415-54 }\end{array}$ & $386 \pm 24$ & $0.95306 \pm 0.00286$ & 360 & 1.70 & $0.95828 \pm 0.00288$ & $342 \pm 24$ \\
\hline $\begin{array}{l}\text { Pro } \\
\text { X-2423-30 }\end{array}$ & $343 \pm 24$ & $0.95822 \pm 0.00280$ & 240 & 1.63 & $0.96187 \pm 0.00281$ & $312 \pm 23$ \\
\hline $\begin{array}{l}\text { Ala } \\
\text { X-2423-35 }\end{array}$ & $413 \pm 25$ & $0.94994 \pm 0.00299$ & 240 & 0.70 & $0.95840 \pm 0.00304$ & $341 \pm 25$ \\
\hline $\begin{array}{l}\text { EAA } \\
\text { X-2438-33 }\end{array}$ & $359 \pm 23$ & $0.95634 \pm 0.00278$ & 84 & 1.41 & $0.95781 \pm 0.00279$ & $346 \pm 23$ \\
\hline
\end{tabular}


Compound-Specific ${ }^{14} \mathrm{C}$ Dating of Amino Acids

All Mary Rose single amino acid dates were statistically indistinguishable from the bulk dates and pass a chi-square test at a $5 \%$ confidence limit, suggesting no difference in the ${ }^{14} \mathrm{C}$ ages of essential and non-essential amino acids. This is what we would expect from a bone that does not have reservoir carbon.

\section{Single Amino Acid ${ }^{14} \mathrm{C}$ Dates for Human Bones from the Schela Cladovei Site, Romania}

Human bones from individual Late Mesolithic skeletons from the Iron Gates site of Schela Cladovei, Romania, and artifacts made from terrestrial mammal (ungulate) bone found in direct association with the human skeletal remains, were selected for analysis. The ${ }^{14} \mathrm{C}$ dates from previous studies have shown that the human bone collagen samples are always significantly older than the ungulate samples by approximately $300-500 \mathrm{yr}$, although it is assumed, based on their intimate association, that the bone points and humans were contemporaneous.

Combined EAAs (Lue, Ile, Met, Tyr, Phe) and single NEAAs (Asp, Hyp, Glu, Ala) were isolated preparatively using the chromatographic method described and ${ }^{14} \mathrm{C}$ dated. Bulk collagen used to separate these amino acids fractions was also dated. The ungulate bones were not available to redate. Some single amino acid dates are missing due to the loss of sample during processing. The data obtained were compared with the data reported in Cook et al. (2001) for ungulate bones (Figure 3 and Table 2). Figure 4 compares the calibrated ${ }^{14} \mathrm{C}$ dates for human bulk, ungulate bulk, and single amino acid determinations.

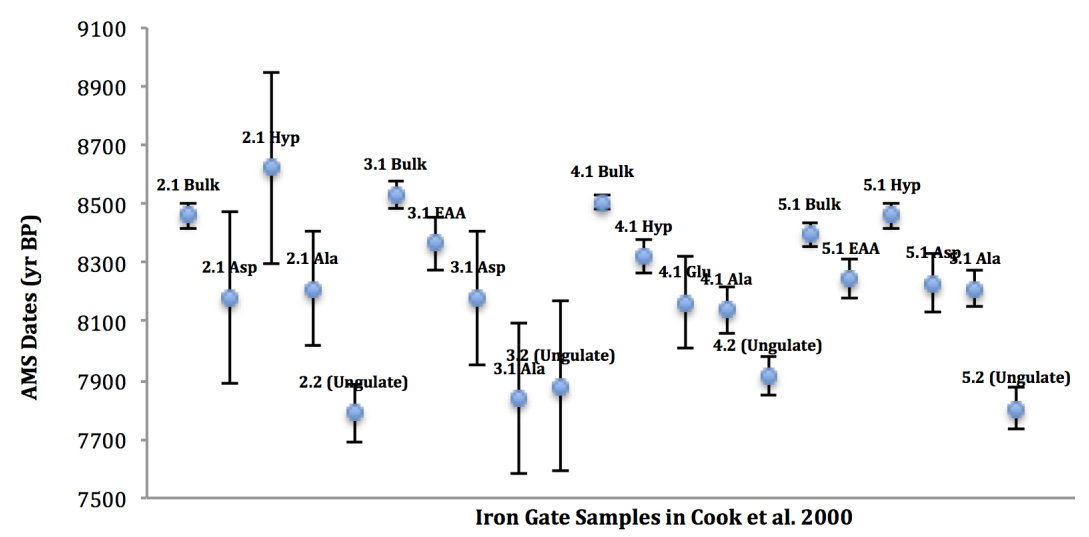

Figure 3 Uncalibrated ${ }^{14} \mathrm{C}$ dates of single AAs and bulk collagen samples for the Iron Gates Mesolithic samples analyzed in this paper (see Cook et al. 2001 for the ${ }^{14} \mathrm{C}$ data associated with ungulate bones).

\section{DISCUSSION}

In evaluating the results, we examined the uncalibrated ${ }^{14} \mathrm{C}$ dates for the single amino acids and bulk collagen for humans (Table 2) and bulk collagen ${ }^{14} \mathrm{C}$ dates for associated ungulate bones (Cook et al. 2001). Large $\pm 1 \sigma$ errors resulting from very small graphite sizes for few of the amino acids hamper the precision of ${ }^{14} \mathrm{C}$ dates and generally this is a problem in our efforts to interpret the results.

The single amino acid dates from Schela Cladovei human bones confirm the presence of diet-based reservoir carbon. For all samples, single NEAAs, especially Ala, Glu, and Asp, provided statistically similar ${ }^{14} \mathrm{C}$ ages. Although EAA measurements for sample IG(D)3.1 and sample IG(D)5.1 were statistically indistinguishable from Ala, a variation in the values appeared to follow a trend with Ala being the youngest. It is important to note that the difference between Ala and bulk is sta- 


\section{S Nalawade-Chavan et al.}

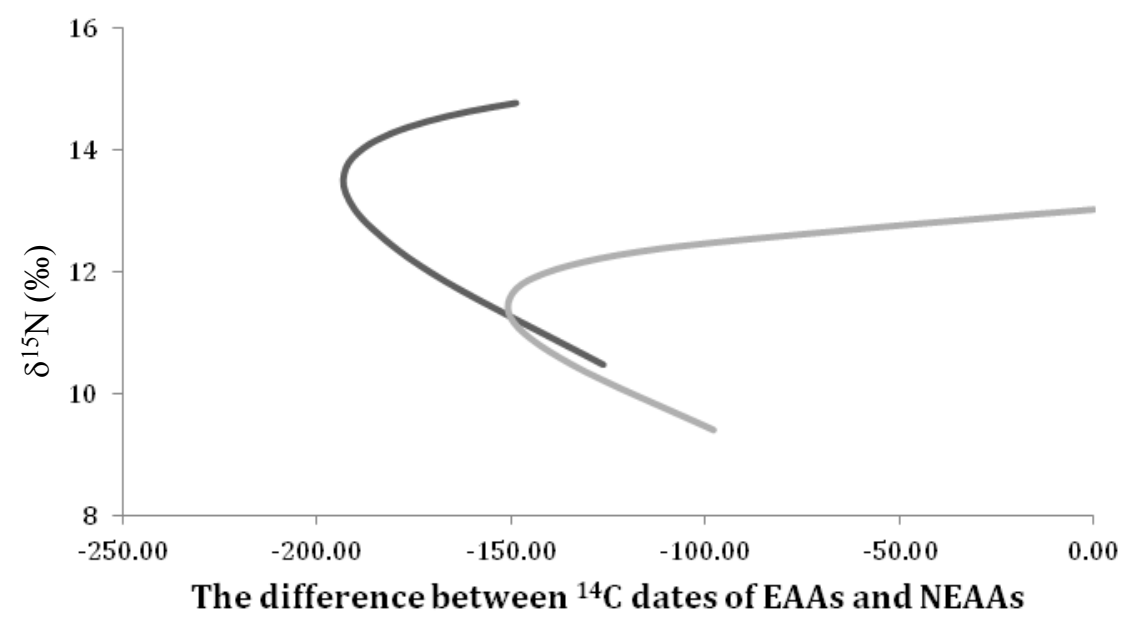

Figure 4 Plot of simulated $\delta^{15} \mathrm{~N}$ versus ${ }^{14} \mathrm{C}$ offset between EAAs and NEAAs (such as Phe and Ala). Total reservoir difference is $400 \mathrm{yr}$. The dark-gray line assumes $50 \%$ of collagen Ala is derived from plant carbohydrate in the diet, for a range of physiologically sensible diets (terrestrial cereals, meat, and freshwater fish), which increase in fish content as indicated by the increasing $\delta^{15} \mathrm{~N}$ values. Note that the maximum ${ }^{14} \mathrm{C}$ difference is half the total reservoir difference and occurs towards the upper end of the range of $\delta^{15} \mathrm{~N}$ values. The light-gray line assumes initially $50 \%$ of collagen Ala is derived from dietary carbohydrate, which decreases linearly to $0 \%$ when the diet has become protein-rich. The ${ }^{14} \mathrm{C}$ difference is greatest for considerably less fish consumption.

tistically significant for samples $\mathrm{IG}(\mathrm{D}) 3.1, \mathrm{IG}(\mathrm{D}) 4.1$, and $\mathrm{IG}(\mathrm{D}) 5.1$ where alanine was younger than EAAs and/or bulk collagen from the same collagen sample as shown using the error-weighted mean method of Ward and Wilson (1978). Alanine dates for sample IG(D)2.1 and IG(D)3.1 were statistically similar to the corresponding ungulate dates. This finding is consistent with the hypothesis that NEAAs may incorporate less reservoir carbon from the diet than is found in EAAs.

Despite these promising results, it remains clear that increased precision is required to determine a statistical difference between EAAs and NEAAs more generally and to evaluate the robustness of this approach for the determination of reservoir effects. Based on a linear relationship between $\delta^{15} \mathrm{~N}$ ranging between $8 \%$ and $17 \%$, the Schela Cladovei individuals were estimated to have diets that included up to $\sim 79 \%$ protein from aquatic dietary sources, corresponding to $\delta^{15} \mathrm{~N}$ of $\sim 15 \%$ (Cook et al. 2001). Jim et al. (2006) suggest, however, that for high-protein diets, NEAAs would become increasingly "similar" to EAAs as more NEAAs may be routed directly from the diet. If this is the case, the difference between EAAs and NEAAs may not be linear with $\delta^{15} \mathrm{~N}$ in the range of $8 \%$ to $17 \%$ at Schela Cladovei. Based on the model explained below, we suggest analysis of samples representing a range of $\delta^{15} \mathrm{~N}$ values might be a better approach to identifying and quantifying a freshwater reservoir effect in humans.

\section{Modeling the Effects of ${ }^{14} \mathrm{C}$ Reservoir Sources on the Dates of Individual Amino Acids}

The magnitude of the Danube reservoir effect depends on how much collagen protein carbon derives from the mainly protein riverine diet, and how much derives from both terrestrial protein (plant and animal) and terrestrial carbohydrate (plant). Available data do not precisely define this. Feeding experiments on pigs (Jim et al. 2006) provide a guide at the single amino acid level. This confirms the biochemical expectation that there is some, and possibly much, incorporation of certain amino acids biosynthesized from dietary carbohydrate into collagen. 


\section{Compound-Specific ${ }^{14} \mathrm{C}$ Dating of Amino Acids}

Table 2 Bulk collagen and amino acid ${ }^{14} \mathrm{C}$ dates for Schela Cladovei human skeletons previously dated by Cook et al. (2001).

\begin{tabular}{|c|c|c|c|c|c|c|}
\hline $\begin{array}{l}\text { Sample ID/ } \\
\text { Fraction/ } \\
\text { Lab nr }\end{array}$ & $\begin{array}{l}{ }^{14} \mathrm{C} \text { age } \mathrm{BP} \\
( \pm 1 \text { error })\end{array}$ & $\begin{array}{l}\mathrm{F}^{14} \mathrm{C} \\
\pm 1 \sigma\end{array}$ & $\begin{array}{l}\text { Vol. } \\
(\mathrm{mL})\end{array}$ & $\begin{array}{l}\text { Graphite } \\
\text { size }(\mathrm{mg})\end{array}$ & $\begin{array}{l}\text { Corrected Fraction } \\
\text { Modern } \pm 1 \sigma\end{array}$ & $\begin{array}{l}\text { Corrected } \\
{ }^{14} \mathrm{C} \text { age BP }\end{array}$ \\
\hline $\begin{array}{l}\text { IG(D) 2.1 Bulk } \\
\text { X-2478-54 }\end{array}$ & $8460 \pm 45$ & $0.34881 \pm 0.00191$ & - & 1.53 & 一 & - \\
\hline $\begin{array}{l}\text { IG(D) 2.1 Asp } \\
\text { X-2479-38 }\end{array}$ & $8370 \pm 280$ & $0.35260 \pm 0.01225$ & 270 & 0.174 & $0.36123 \pm 0.01289$ & $8180 \pm 290$ \\
\hline $\begin{array}{l}\text { IG(D) 2.1 Нyp } \\
\text { X-2479-39 }\end{array}$ & $8720 \pm 320$ & $0.33755 \pm 0.01340$ & 180 & 0.206 & $0.34187 \pm 0.01379$ & $8620 \pm 325$ \\
\hline $\begin{array}{l}\text { IG(D) 2.1 Ala } \\
\text { X-2479-40 }\end{array}$ & $8580 \pm 190$ & $0.34373 \pm 0.00795$ & 420 & 0.144 & $0.35986 \pm 0.00878$ & $8210 \pm 195$ \\
\hline $\begin{array}{l}\text { IG(D) 3.1 Bulk } \\
\text { X-2478-55 }\end{array}$ & $8530 \pm 45$ & $0.34590 \pm 0.00190$ & - & 1.54 & - & - \\
\hline $\begin{array}{l}\text { IG(D) 3.1 EAA } \\
X-2479-41\end{array}$ & $8380 \pm 90$ & $0.35225 \pm 0.00378$ & 80 & 0.311 & $0.35289 \pm 0.00380$ & $8365 \pm 90$ \\
\hline $\begin{array}{l}\mathrm{IG}(\mathrm{D}) 3.1 \mathrm{Asp} \\
\mathrm{X}-2479-42\end{array}$ & $8470 \pm 220$ & $0.34823 \pm 0.00955$ & 270 & 0.115 & $0.36129 \pm 0.01033$ & $8180 \pm 230$ \\
\hline $\begin{array}{l}\text { IG(D) 3.1 Ala } \\
\text { X-2479-43 }\end{array}$ & $8330 \pm 240$ & $0.35457 \pm 0.01052$ & 420 & 0.113 & $0.37712 \pm 0.01195$ & $7835 \pm 255$ \\
\hline $\begin{array}{l}\text { IG(D) 4.1 Bulk } \\
\text { X-2478-56 }\end{array}$ & $8505 \pm 25$ & $0.34682 \pm 0.00187$ & - & 1.90 & - & - \\
\hline $\begin{array}{l}\text { IG(D) 3.1 Нyp } \\
\text { X-2479-56 }\end{array}$ & $8365 \pm 55$ & $0.35309 \pm 0.00238$ & 180 & 0.504 & $0.35500 \pm 0.00241$ & $8320 \pm 55$ \\
\hline $\begin{array}{l}\text { IG(D) 4.1 Glu } \\
\text { X-2479-46 }\end{array}$ & $8380 \pm 150$ & $0.35220 \pm 0.00652$ & 240 & 0.138 & $0.36191 \pm 0.00691$ & $8165 \pm 155$ \\
\hline $\begin{array}{l}\text { IG(D) 4.1 Ala } \\
\text { X-2479-47 }\end{array}$ & $8320 \pm 90$ & $0.35482 \pm 0.00379$ & 420 & 0.286 & $0.36307 \pm 0.00398$ & $8140 \pm 90$ \\
\hline $\begin{array}{l}\text { IG(D) 5.1 Bulk } \\
\text { X-2478-57 }\end{array}$ & $8395 \pm 40$ & $0.35165 \pm 0.00179$ & - & 1.74 & - & - \\
\hline $\begin{array}{l}\text { IG(D) 5.1 EAA } \\
\text { X-2479-48 }\end{array}$ & $8255 \pm 65$ & $0.35780 \pm 0.00280$ & 80 & 0.393 & $0.35840 \pm 0.00281$ & $8245 \pm 65$ \\
\hline $\begin{array}{l}\text { IG(D) 5.1 Asp } \\
\text { X-2479-49 }\end{array}$ & $8330 \pm 100$ & $0.35454 \pm 0.00435$ & 270 & 0.334 & $0.35898 \pm 0.00447$ & $8230 \pm 100$ \\
\hline
\end{tabular}

We have made a model that compares the ${ }^{14} \mathrm{C}$ isotopic composition of collagen amino acids wholly derived from dietary protein (such as Phe) with that of an amino acid largely derived (biosynthesized) from dietary carbohydrate (Ala is a candidate due to its significant flux in animals but other NEAAs such as Asp or Glu are possible). It should be noted that the degree of biosynthesis is not well known and is likely to be a variable in the model, although a value of about $50 \%$ biosynthesis on average for NEAAs would be compatible with feeding studies (Jim et al. 2006) and with other circumstantial physiological evidence.

Such a model evaluates the difference in ${ }^{14} \mathrm{C}$ between amino acid (AA) pairs for a given diet, reservoir value, and degree of biosynthesis. As the relative quantity of river fish increases, so does the AA ${ }^{14} \mathrm{C}$ difference, until fish dominates the diet and the difference declines to zero. Such models suggest quite large differences when fish consumption is fairly high $(60-80 \%$ of protein, as indicated e.g. by $\delta^{15} \mathrm{~N}$ values). In particular, the degree of amino acid biosynthesis from dietary carbohydrate may decrease when dietary protein is abundant. A second model that allows such biosynthesis to fall to zero as total dietary protein increases to $25 \%$ of total energy predicts that $\mathrm{AA}{ }^{14} \mathrm{C}$ differences will disappear at considerably lower levels of fish consumption. We have not yet sought to measure material that tests such dietary situations. Figure 4 illustrates the form of the modeled results. 


\section{S Nalawade-Chavan et al.}

\section{CONCLUSIONS}

Beyond the obvious benefits of a method that decreases extraneous contamination in the dated component of archaeological bone, single amino acid dates have the potential to determine the presence of multiple carbon reservoirs present in essential and non-essential amino acids. Taken together, these methodological developments have huge potential for contributing to future work in archaeological science worldwide.

This paper has presented an improved mixed-mode chromatographic technique that facilitates the separation of underivatized non-essential amino acids besides the previously separated non-essential aspartic acid, glutamic acid, hydroxyproline, serine, threonine, glycine, proline, and alanine preparatively from hydrolyzed bone collagen. Measures were taken to minimize the background carbon added, the majority of which was contributed by column bleed and significantly reduced by the removal of an acid separation step. This extraneous carbon being ${ }^{14} \mathrm{C}$-dead is expected to affect modern samples more, while its effect remains insignificant in older samples. A correction algorithm was formulated to adjust the AMS dates based on the amount of mobile phase collected and graphite size.

Applying single amino acid methods to attempt to circumvent reservoir effects in human bone collagen was undertaken. The results were affected by poor measurement precision in 2 cases. Where precision was improved, we found a statistical difference between bulk human bone collagen and a NEAA (Ala) in one instance. We also found, however, that the Ala determinations were distinguishable from the ungulate bone results that represent the likely true age of the Mesolithic burials. This suggests the possibility that high-protein diets such as we find in the Iron Gates might be an important influence. A model shows that when fish consumption is high, the differences between single amino acid ${ }^{14} \mathrm{C}$ concentrations decline. Further work is required to test this. We are currently focusing on dating single amino acids from bones with lower $\delta^{15} \mathrm{~N}$ values, which likely represent diets characterized by lower levels of freshwater fish protein.

In view of the ambiguity in the model results, a carefully nuanced approach will be necessary to investigate reservoir effects recorded in different diets. Single amino acids from samples known to have marine carbon with varied $\delta^{15} \mathrm{~N}$ values will be ${ }^{14} \mathrm{C}$ dated to further investigate the diet-based freshwater reservoir effect.

\section{ACKNOWLEDGMENTS}

We are grateful to all the people at the ORAU, especially Angela Bowles who helped with this project. We are also grateful to Dr Anat Marom for her support.

\section{REFERENCES}

Ambrose S, Norr L. 1993. Experimental evidence for the relationship of the carbon isotope ratios of whole diet and dietary protein to those of bone collagen and carbonate. In: Lambert JB, Grupe G, editors. Prehistoric Human Bone: Archaeology at the Molecular Level. Berlin: Springer. p 1-37.

Beavan N, Sparks R. 1998. Factors influencing ${ }^{14} \mathrm{C}$ ages of the Pacific rat Rattus exulans. Radiocarbon 40(2): 601-13.

Beavan-Athfield N, McFadgen B, Sparks J. 2001. Environmental influences on dietary carbon and ${ }^{14} \mathrm{C}$ ages in modern rats and other species. Radiocarbon 43(1): 7-14.

Brock F, Higham T, Ditchfield P, Bronk Ramsey C. 2010. Current pretreatment methods for AMS radiocarbon dating at the Oxford Radiocarbon Accelerator Unit (ORAU). Radiocarbon 52(1):103-12.

Bronk Ramsey C, Ditchfield P, Humm M. 2004a. Using a gas ion source for radiocarbon AMS and GC-AMS. Radiocarbon 46(1):25-32.

Bronk Ramsey C, Higham T, Leach P. 2004b. Toward high-precision AMS: progress and limitations. Radio- 


\section{Compound-Specific ${ }^{14} \mathrm{C}$ Dating of Amino Acids}

carbon 46(1):17-24.

Bruns M, Levin I, Munnich K, Hubberten H, Fillipakis S. 1980. Regional sources of volcanic carbon dioxide and their influence on ${ }^{14} \mathrm{C}$ content of present-day plant material. Radiocarbon 22(2):532-6.

Cook G, Bonsall C, Hedges REM, McSweeney K, Boroneanţ V, Pettitt PB. 2001. A freshwater diet derived ${ }^{14} \mathrm{C}$ reservoir effect at the Stone Age sites in the Iron Gates gorge. Radiocarbon 43(2A):453-60.

Cook GT, Bonsall C, Hedges REM, McSweeney K, Boroneant V, Bartosiewicz L, Pettitt PB. 2002. Problems of dating human bones from the Iron Gates. Antiquity 76(291):77-85.

Devlin T. 1998. Textbook of Biochemistry with Clinical Correlations. 3rd edition. New York: Wiley-Liss.

Higham T, Warren R, Belinskij A, Härke H, Wood R. 2010. Radiocarbon dating, stable isotope analysis, and diet-derived offsets in ${ }^{14} \mathrm{C}$ ages from the Klin-Yar site, Russian North Caucasus. Radiocarbon 52(2):653-70.

Jim S, Jones V, Ambrose S, Evershed R. 2006. Quantifying dietary macronutrient sources of carbon for bone collagen biosynthesis using natural abundance stable carbon isotope analysis. British Journal of Nutrition 95(6):1005-62.

Lambert B, Grupe G. 1993. Prehistoric Human Bone: Archaeology at the Molecular Level. Berlin: Springer.

Longin R. 1971. New method of collagen extraction for radiocarbon dating. Nature 230(5291):241-2.

McCullagh J, Marom A, Hedges R. 2010. Radiocarbon dating of individual amino acids from archaeological bone collagen. Radiocarbon 52(2):620-34.

Marom A, McCullagh J, Higham T, Sinitsyn A, Hedges R. 2012. Single amino acid radiocarbon dating of Upper Paleolithic modern humans. Proceedings of the
National Academy of Sciences of the USA 109(17): 6878-81.

O'Connell T, Hedges R. 1999. Isotopic comparison of hair and bone: archaeological analyses. Journal of Archaeological Science 26(6):661-5.

O'Connell T, Healey M, Hedges R, Simpson AHW. 2001. Isotopic comparison of hair, bone and nail: modern analyses. Journal of Archaeological Science 28(11):1247-55.

Reeds P. 2000. Dispensable and indispensable amino acids for humans. Journal of Nutrition 130(7):1835S$1840 \mathrm{~S}$.

Reimer PJ, Baillie MGL, Bard E, Bayliss A, Beck WJ, Bertrand C, Blackwell PG, Buck CE, Burr GS, Cutler KB, Damon PE, Edwards RL, Fairbanks RG, Friedrich M, Guilderson TP, Hughen KA, Kromer B, McCormac FG, Manning S, Bronk Ramsey C, Reimer RW, Remmele S, Southon JR, Stuiver M, Talamo S, Taylor FW, van der Plicht J, Weyhenmeyer CE. 2004. IntCa104 terrestrial radiocarbon age calibration, 0-26 cal kyr BP. Radiocarbon 46(3):1029-58.

Reimer PJ, Baillie MGL, Bard E, Bayliss A, Beck JW, Blackwell PG, Bronk Ramsey C, Buck CE, Burr GS, Edwards RL, Friedrich M, Grootes PM, Guilderson TP, Hajdas I, Heaton T, Hogg AG, Hughen KA, Kaiser KF, Kromer B, McCormac FG, Manning SW, Reimer RW, Richards DA, Southon JR, Talamo S, Turney CSM, van der Plicht J, Weyhenmeyer CE. 2009. IntCa109 and Marine09 radiocarbon age calibration curves, 0-50,000 years cal BP. Radiocarbon 51(4): 1111-50.

Ward G, Wilson S. 1978. Procedures for comparing and combining radiocarbon age determinations: a critique. Archaeometry 20(1):19-31. 